\title{
Effectiveness Analysis of Non-formal Education Learning in Central Java
}

\author{
Tri Joko Raharjo \\ Department of Nonformal Education \\ Universitas Negeri Semarang
}

Gedung A Kampus Sekaran Gunungpati Semarang 50229,

Indonesia

trijokoraharjo@mail.unnes.ac.id

Fakhruddin

Department of Nonformal Education

Universitas Negeri Semarang

Gedung A Kampus Sekaran Gunungpati Semarang 50229,

Indonesia

\begin{abstract}
The effectiveness of learning is influenced by various factors, this study aims to determine the magnitude of the effect of: (a) the working climate, and supervising the commitments learning tutors; (b) work climate, and supervision of the effectiveness of learning for learning; and (c) determining the amount of commitment influence officials learned as a moderator variable of the working climate and the power of learning supervision for learning effectiveness. Variables examined that the working climate Sanggar Kegiatan Belajar (SKB) (X1), learning supervision (X2), and committed tutors (X3); while the dependent variable is the effectiveness of learning (Y). The total sample of 200 tutors, sampling techniques sample the region, in the form of clusters that are determined in stages. Sample selection technique is "proportional random cluster sampling". Methods of data collection using questionnaires, while data analysis techniques using path analysis. Research findings show: (a) the level of influence the working climate of the commitment officials learned of $43.54 \%$, the effect of supervision of learning for tutors commitments amounted to $43.54 \%$.; (b) the effect of climate variables work against the effectiveness of learning by $49.20 \%$, the effect of supervision of learning for learning effectiveness by $41.20 \%$; and (c) variable commitment tutors can be a mediator for achieving efficiency. The study, which means to increase the effectiveness of learning in addition to support SKB work climate and learning supervision required mediation commitment tutors.
\end{abstract}

Keywords-working climate, instructional supervision, commitment, effectiveness of learning

\section{INTRODUCTION}

Education is an important part of the national development process that will determine the economic growth of a country. Education is also an investment in human resource development, and the increased importance of human resource development in a sustainable manner is

\author{
Joko Sutarto \\ Department of Nonformal Education \\ Universitas Negeri Semarang \\ Gedung A Kampus Sekaran Gunungpati Semarang 50229, \\ Indonesia
}

one of the policy to improve the quality of education. Efforts to improve the quality of education is largely determined by the effectiveness of learning. It is recognized that the quality of non-formal education in general and learning outcomes of students in particular are the result of a process of interaction of various factors such as the competence of educators, committed educators learners, the role of leadership, work climate, curriculum, textbooks, laboratory, learning methods, legislation or regulations in the field of education, and a variety of inputs as well as other conditions that affect the learning process. Likewise, the study group work behavior is determined by an atmosphere or climate of the working environment in the study group. In developed countries, research on the working climate in the educational unit developed well established and provide a significant contribution to the formation of units of an effective education. It is asserted that if educators feel a conducive working atmosphere in pendidikanya unit, it can be expected learners will achieve satisfactory academic achievement. Brookover et al [1] suggested that the working climate affect the behavior or actions of the entire community of the educational unit, particularly on the academic achievement of students. Besides working climate, learning effectiveness is also determined by the strength of learning leadership's supervision unit of the organization. The research findings Charles et al [2], Okendu [3], as well as Alimi and Akinfolarin [4], confirms that the supervision of learning undertaken organizational unit leadership education has an impact on increasing the achievement of learners. The success or failure of an education unit to achieve its objectives, are determined by the human element in it. This means that efforts to increase the effectiveness of nonformal education learning is not enough just to rely on the ability of modern management techniques, but it must be 
coupled with the development of organizational behavior as arts management, focusing concern on the human approach. As stated by Taylor and John [5] that a service organization such as the education unit is built for a specific purpose and fulfill the mission it has set. In other words, the member organizations (citizen study groups) mainly tutors must have a commitment to the mission and objectives, primarily directed to the effectiveness of learning. Based on the phenomena that occur in the field, this research focused on uncovering work climate variables, and the power of supervision of learning as a mediating influence tutors commitment to learning effectiveness. Optimizing the effectiveness of non-formal learning requires support from the education of the working climate factors, and supervision of learning are built; and mediated factor of the commitment of the tutors. The purpose of this study is to determine the magnitude of the effect of: (a) the working climate, and supervising the commitments learning tutors; (b) work climate, and supervision of the effectiveness of learning for learning; and (c) determining the amount of commitment influence officials learned as a moderator variable of the working climate and the power of supervision of learning for learning effectiveness.

\section{LITERATURE REVIEW}

Learning is a deliberate attempt, aimed, and controlled so that others learn Miarso [6] and behavioral changes were relatively settled as a result of the experience Wittig [7]. Attempt to make others learn to do by someone who has the ability in designing, developing, utilizing, managing, and assessing the learning process. Learning implies more than teaching as understood as the presentation of teaching materials. Learning is a mental process that are personal, takes place in an active interaction with the environment to produce changes in knowledge, skills, and attitudes Winkel [8]. Equality as an educational learning management systems can not be separated from the three main elements, namely input, process elements and element results Hoy and Miskel [9]; Hughes [10]. The success of the management learning is influenced by inputs of instrumental and environmental input. Instrument input as the focus of this study is a factor working climate, instructional supervision, while the factors lingkunganadalah commitment tutors. Efforts to improve quality and productivity in any field, not in spite of the management system developed, so that very commitment factor plays an important role and determine Stephanie [11]; Richard [12]. One subordinate involvement in the dynamics of the organization's participation in the decision-making process based on the authority granted by the leadership to them

It was emphasized that if the work climate, instructional supervision, and commitment of educators has been optimized to the maximum, it can be expected to achieve the learning effectiveness. The climate of the organization objectively exists in every organization, and influence the behavior of members of the organization, but can only be measured indirectly through the perceptions of members of the organization Wirawan [13]. Dimensions working climate are the elements, factors, traits, or characteristics of the organization's work climate variables. Dimensions organization working climate are of various types and different in every organization. Studies conducted Stringer, indicates that the characteristics or dimensions of organizational work climate affect the motivation of members of the organization to behave in certain ways Stringer [14]. Therefore, the organization's work climate can be described and measured in terms of these dimensions. As a social energy, work climate labor is a practice that stems from the perception with all members of the organization, making it a value system that binds them to comply with the organization's goals and expectations. Working climate work is so important, so it can be a differentiating factor from one organization to another organization.

Results of a study conducted by experts showed that growing organizations because it can handle people with reference to the values that support. In a further development of these values into a kind of ideology of an organization Minner [15]. Theory learning supervision of Lovell and Wiles [16] mentions supervision activities of learning as interaction between supervisors and educators in an effort to help educators improve learning situations effectively and efficiently, Learning situations include the objectives, resources, methods, techniques, as well as the management of learners and the classroom environment. Learning situations that should be maintained, improved and increased through service learning supervision activities. The view that focuses on the achievement of learning supervised learning effectiveness uncovered by Glickman [17] which states that supervision of learning as an aid to educators in an effort to improve its ability to achieve the learning objectives. Masaong [18] confirms the statement Glickman to formulate instructional supervision as a support service to educators to develop qualities and professionalism in learning, so as to realize the study of students is optimal. Supervision diterminan learning is an important factor in ongoing professional development to enhance the ability of educators to reflect, analyze and evaluate performance Reid [19]. Supervision of learning a role as one of the efforts to improve the quality of education if implementation in accordance with the objectives. The purpose of supervision of learning based on the conclusions Masaong [18] are: (1) to guide and facilitate educators develop professional competence; (2) to motivate educators to perform their duties effectively; (3) help educators manage the curriculum and learning; and (4) help educators foster potential learners to develop optimally.

The concept of commitment from supervisors adaptation of organizational commitment. The commitment in the organization according to Zangaro [20] is divided into two views. The first view refers to the organizational commitment as behavioral. This approach exemplifies an employee who is committed to the organization for their 
salaries, as in the writings of Becker and Salancik. The second view refers to the organizational commitment as an attitude, approach, in which the organizational commitment is defined as the state of an employee who maintains membership in the organization in order to achieve personal goals, such as in the writings of Blau and Boal. In subsequent years, these two views are combined by Etzioni and Kanter. Kanter commitment definitions developed by Mowday, Steers and Porter in Mguqulwa [21] mentions three factors that can foster commitment to the organization, namely: (1) a strong belief and acceptance of the goals and values of the organization; (2) a willingness to exert great effort on behalf of the organization; and (3) a strong desire to maintain membership in the organization.

\section{METHOD}

This study aimed to examine the influence of variables related to climatic factors of work, supervision of learning, commitment tutors and learning effectiveness of non-formal education is measured from the behavior of tutors in the learning plan, implementing the learning, and assess the learning process. Type of research variables are independent variables (affecting) the work climate that SKB (X1), supervision of learning undertaken SKB head (X2), and committed tutors (X3); while the dependent variable (affected) in this study was the effectiveness of learning (Y).

The variables of this study can be presented in the form of a paradigm as follows:

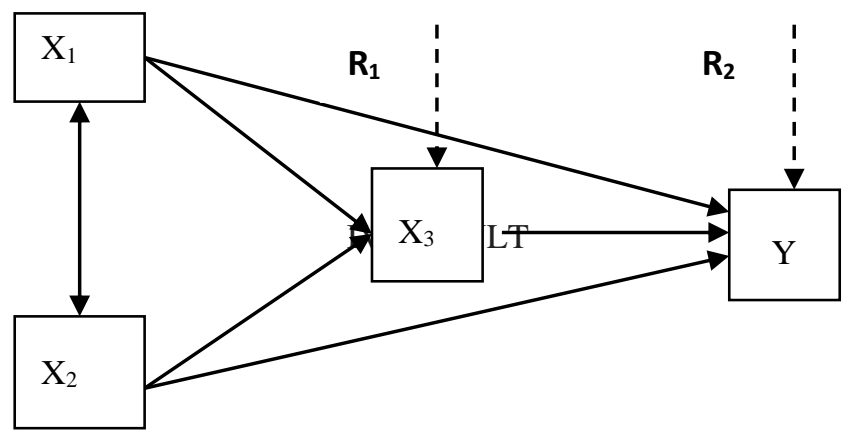

Fig 1. Relationship Research Variables

\section{Result of Research}

\section{A. The influence of the working climate and the commitment of supervisory learning tutors.}

The calculation based on those criteria and the influence of the working climate, and supervising the commitment tutors as shown in Table 1 and Table 2 below.
Mechanical sampling or sample selection technique using a sample region, in the form of clusters that are determined in stages (Multy stage). The research sample of 200 tutors Sanggar Kegiatan Belajar (SKB) spread in 27 regencies /cities in Central Java. The rationale for establishing officials learned as samples are due to: (a) directly tutors who take part in the planning process of learning, the implementation of learning and learning assessment; (b) the working climate and academic supervision carried out by the head of SKB is knowing and judging are tutors, and tutors who know the commitment is the tutors themselves. Based on the formulation of the problem and research objectives as stated in the background, then the hypothesis test conducted by the path analysis (path analysis) to determine the relationship directly or indirectly. Before analyzed first in distribution normality test data, linearity and homogeneity. Normality test results in getting significant value of each is $0.935 ; 0.648$; and 0,729 , these numbers are dramatically higher in comparison with the $5 \%$ significance (0.05). It illustrates the distribution of normal distribution of data. Linearity test shows all study variables: $\mathrm{Fh}(\mathrm{X} 1=5.710, \mathrm{X} 2=4.712, \mathrm{X} 3=5.728)>\mathrm{Ft}=4.00$. This means that all variables (SKB work climate, and committed tutors have a linear relationship to $\mathrm{Y}$ (the effectiveness of learning).

TABLE I. OUTPUT COEFFICIENT ANALYSIS OF DETERMINATION EFFECT SKB WORK CLIMATE AND THE COMMITMENT TUTORS

\begin{tabular}{|c|c|c|c|c|}
\hline \multicolumn{3}{|c|}{ Mode } & \multirow{2}{*}{$\begin{array}{l}\text { Adjusted R } \\
\text { Square }\end{array}$} & \multirow{2}{*}{$\begin{array}{l}\text { Std. Error of the } \\
\text { Estimate }\end{array}$} \\
\hline 1 & $\mathbf{R}$ & R Square & & \\
\hline 1 & $.585^{\mathrm{a}}$ & .347 & .347 & 5.894 \\
\hline
\end{tabular}

Predictors: (Constant), Commitment Tutors

Based on the analysis of determination coefficient obtained the $\mathrm{r}$ value of 0.585 which is located in the interval from 0.40 to 0.599 with a pretty strong criteria. The amount of influence the working climate of the commitment officials learned of $(0.585) 2 \times 100 \%=34.70 \%$. This means that the working climate variables SKB contributed by $34.70 \%$ in explaining changes in commitment tutors variable 


\section{TABLE II. OUTPUT COEFFICIENT ANALYSIS OF DETERMINATION \\ EFFECT SUPERVISION OF LEARNING AND THE COMMITMENT TUTORS}

\begin{tabular}{lrrrr}
\hline Mod & & & Adjusted & Std. Error of the \\
el & R & R Square & R Square & Estimate \\
\hline & & & & \\
2 & $.756^{\mathrm{a}}$ & .512 & .586 & 4.325 \\
\hline
\end{tabular}

Predictors: (Constant), Commitment

Tutors

Based on the analysis of determination coefficient obtained the $r$ value of 0.756 which is located in the interval 0.60 to 0.799 with strong criteria. Thus it can be stated that the effect of variable supervision of the commitments learning tutors are in the strong category. The magnitude of the effect of supervision of learning for tutors commitments) amounted to $(0.756) 2 \times 100 \%=43.54 \%$. This means that the variable supervision of learning a contribution of $43.54 \%$ to explain the changes that occur in the variable commitment tutors.

B. The effect of working climate, and instructional supervision for learning effectiveness

The calculation based on those criteria and the influence of the working climate, and instructional supervision of the effectiveness of learning in Table 3 and Table 4 below.

TABLE III. OUTPUT COEFFICIENT ANALYSIS OF DETERMINATION

EFFECT SKB WORK CLIMATE AND THE EFFECTIVENESS OF LEARNING

\section{Adjusted R Std. Error of the}

\begin{tabular}{lrrrr} 
Model R & R Square & Square & \multicolumn{2}{c}{ Estimate } \\
\hline 3 & $.702^{\mathrm{a}}$ & .482 & .487 & 5.227 \\
\hline
\end{tabular}

Predictors: (Constant), Effectiveness of

learning

Based on the analysis of determination coefficient obtained the $r$ value of 0.702 which is located in the interval 0.60 to 0.799 with strong criteria. Thus it can be stated that the effect of work climate variable against the effectiveness of learning category SKB strong enough. The magnitude of the effect of work climate variables work against the effectiveness of learning (.702) $2 \times 100 \%=49.20 \%$. This means that the work climate variables SKB effect of $49.20 \%$ in describing the changes that occur in the variable effectiveness of learning.
TABLE IV. OUTPUT COEFFICIENT ANALYSIS OF DETERMINATION EFFECT LEARNING SUPERVISION AND THE EFFECTIVENESS OF LEARNING

\begin{tabular}{|c|c|c|c|c|}
\hline Model I & & R Square & $\begin{array}{l}\text { Adjusted R } \\
\text { Square }\end{array}$ & $\begin{array}{l}\text { Std. Error of the } \\
\text { Estimate }\end{array}$ \\
\hline 4 & $.756^{\mathrm{a}}$ & .412 & .586 & 4.325 \\
\hline
\end{tabular}

Predictors: (Constant), Effectiveness of

learning

Based on the analysis of determination coefficient obtained the $r$ value of 0.756 which is located in the interval 0.60 to 0.799 with strong criteria. Thus it can be stated that the effect of variable learning supervision of the effectiveness of learning in the category is strong enough. The amount of influence on the effectiveness of learning instructional supervision of (0.756) $2 \times 100 \%=41.20 \%$. This means that the variable supervision of learning a contribution of $41.20 \%$ to explain the changes that occur in the variable effectiveness of learning.

C. Effect of commitment tutors as moderator variable of working climate and the power of instructional supervision for learning effectiveness.

The results of the analysis through SPSS regression equation shows: (a) the amount of influence the working climate of the commitment SKB officials learned of $34.70 \%$; (b) the amount of influence the learning undertaken supervision of the head of the SKB against commitments officials learned of $43.54 \%$; (c) the amount of influence the working climate SKB to learning effectiveness by $49.20 \%$; (d) the amount of influence the learning undertaken supervision SKB head towards learning effectiveness by $41.20 \%$. The results of path analysis is shown in figure 2 below.

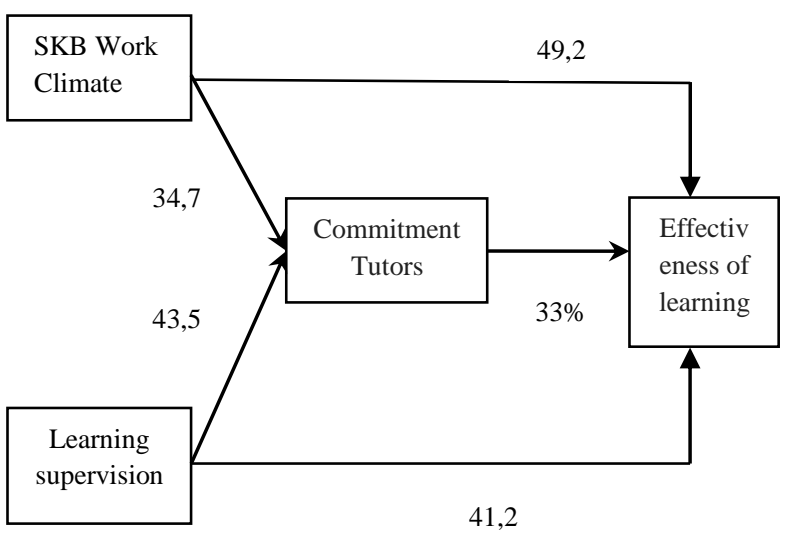

Figure 2. Results Path Analysis 
The results of path analysis showed that the commitment tutors directly influence the effectiveness of study and can affect climate indirectly that is of working and learning supervision. The amount of direct influence is 0.64 while the indirect effect of: $(0,512 \times 0,645)=0.330$. Results of testing the significance of mediating variables obtained $t$ value of 1.17. Therefore $t$ value is smaller than table at a significance level of 0.05 is equal to 1.98 , it can be concluded that the mediation coefficient 0.330 means there is significant mediating effect. Based on the results of path analysis and testing the significance of mediating variables above, it can be stated that the commitment variable tutors can be a mediator for achieving efficiency The study, which means to increase the effectiveness of learning in addition to the support of the working climate and supervision of learning required mediation commitment officials learned that the effectiveness of learning can realized in managing non-formal education program.

\section{DISCUSSION}

Based on the results of path analysis and testing significance of mediating variables above, it can be stated that the commitment variable tutors can be a mediator for achieving efficiency The study, which means to increase the effectiveness of learning in addition to support SKB work climate and learning supervision required mediation commitment tutors. This finding means that the effectiveness of learning is influenced by a work climate that occurred and created the SKB. Organizations on the background of the SKB is highly dependent on the commitment of tutors. As it is known that the behavior of members of an organization different from one another, it is associated with how a person's perception of work and the working environment is a system of organization. The effectiveness of learning is a process of interaction between the private tutors with their surroundings. This means that a conducive working environment, will encourage tutors to work in earnest. Working climate is formed of eight indicators, namely: their work rules, upholding the norms and customs prevailing in the study groups, to create a family atmosphere, working environment supports learning, create transparency in the decision-making lesson, relations head of SKB with tutors intertwined familiar, a study support the learning process, and the existence of adequate incentives for tutors. Obtaining such a condition means their sense of satisfaction, pleasure, and self unencumbered tutors who in turn learning behaviors shown increasing

Based on the findings in the study, the creation and supervision work climate SKB, SKB learning by necessary so that the effectiveness of learning can be maintained continuously and the need for mediation of commitment tutors as the main subject of the implementation of the learning process. As a statement given Masaong [18] that the supervision activities of learning will be effective if supported by the commitment of educators as the main perpetrators of the learning process. Placement tutors commitment as a moderator variable of the working climate and supervision SKB learning by the head of a development of the previous studies. The previous study concluded the relationship between job climate commitments Fadli [22], academic commitments Chen [23]; Forward [24] ; Guney [25] and a commitment to effectiveness learning Ruswenda [26]; Hamadi [27]. Therefore, based on the research findings indicate the importance of the creation of the SKB working climate and the need for supervision by the head of SKB learning in support of the growing commitment of tutors. Commitment tutors did not appear suddenly, but rather arise from the existence of a conducive working environment and the effectiveness of supervision of learning undertaken SKB head; and in turn committed tutors act as mediator achievement of learning effectiveness. Thus, the increase in the working climate and supervise the implementation of learning periodically be implemented to enable tutors to increase its commitment to duty. Commitment tutors should receive maximum attention in order to create learning effectiveness

Several studies and views to support a finding of this study include: research Rodwell [28] about the practice of organizational communication in the context of human resource management, independent variables: communication work, work regulations, commitment to the task, and employee incentives, variable dependent: work behaviors; the results of the study concluded that all independent variables associated positive and significant impact on the dependent variable either partially or simultaneously; Steffen study [11] of the climatic influences of work organization as a determinant of quality of service, independent variables: the commitment of staff, work rules, job descriptions, and labor relations. It was emphasized that the commitment of staff, work rules, clarification of the task, and the working relationship marred openness is positively correlated to the dependent variable, namely the quality of service.

\section{CONCLUSION AND SUGGESTION}

\section{A. Conclusion}

- SKB work climate and learning supervision strong influence on the commitment of tutors, with the amount of $34.70 \%$; and $43.54 \%$.

- SKB work climate and supervision of learning strong influence on the effectiveness of learning, with the magnitude of the effect of $49.20 \%$; and $41.20 \%$.

- Commitment tutors directly influence the effectiveness of study and can affect climate indirectly through working and learning supervision. Commitment tutors can be a mediator for achieving efficiency. The study, which means to increase the 
effectiveness of learning in addition to the support of the working climate and learning supervision required mediation commitment officials learned that the effectiveness of learning can be realized in managing non-formal education program.

\section{B. Suggestion}

- In connection with the working environment, it is necessary to create an environment conducive for the tutors gain comfort in the work, and these conditions will provide positive support for the tutors to actualize himself. Strengthening work climate that is believed to support the effectiveness of learning is their work rules referenced in the learning process, the atmosphere/work climate that supports the learning process, the openness in decision making learning, created the close relationship between the head of SKB and tutors, and the need to strive for the improvement of adequate incentives for tutors.

\section{REFERENCES}

[1] Brookover, W. B., Schweitzer, J. H., Schneider, J. M., Beady, C. H., Flood, P. K., \& Weisenbaker, J. M, "Elementary school social climate and school achievement,".American Educational Research Journal, Vol 15, pp. 301-318, 1978.

[2] Charles, T., Kimutai, C. K., dan Zachariah, K. The Impact of Head Teachers' Supervision of Teachers on Students' Academic Performance. Journal of Emerging Trends in Educational Research \& Policy Studi, Vol. 3 No. 3. pp. 299-306. 2012.

[3] Okendu, J. N. The Influence of Instructional Process and Supervision on Academic Performance of Secondary School Students of Rivers State, Nigeria. Academic Research International, Vol. 3 No. 1. pp. 332-338. 2012.

[4] Alimi, O. S. dan Akinfolarin, C. A. Impact of Selected Modes of Instructional Supervision Activities on Students Academic Performance in Senior Secondary Schools in Ondo State, Nigeria. Education Research Journal, Vol. 2 No. 1. pp. 1-6. 2012.

[5] Taylor, John Wesley, dan John, M Charan.. Leadership Approach, School Climate, and Teacher Commitment: A Philippine Perspective. Christian Education Journal. Spring, Vol 6 pp.106. Proquest Education Journals. 2002.

[6] Miarso,Yusufhadi. 2004. Education Technology. Jakarta: Prenada Media.

[7] Wittig, Arno F. 1981. Theory and Problems of Psychology of Learning. New York: McGraw-Hill, Inc.

[8] Winkel, W.S. 1999. Instructional Psychology. Jakarta: Grasindo.

[9] Hoy, Wayne K. \& Miskel, Cecil G. 1991. Educational Administration, Theory, Research, Practice. Fourth Edition. New York: McGraw-Hill, Inc.

[10] Hughes, P. W. 1991. Teachers' professional development. Melbourne, Victoria: Australian Council for Educational Research.
- In order to increase the effectiveness of learning is required to provide education and training development of competence, especially pedagogical and professional competence of tutors, especially the training of planning and development of methods and media learning, and assessment model learning process and results based on the philosophy, principles, and approaches of non-formal education, as competence development is believed to improve the quality of the learning process, and in turn can enhance the effectiveness of learning.

- Implementation of supervision of learning as much as possible is done periodically because it may increase the commitment of tutors and in turn can enhance the effectiveness of learning. Efforts to maintain the commitment of tutors to do with the provision of adequate welfare for officials learned, for example, ease of seminars, and ease of proposing promotions and rank.
[11] Stephaine R. 1997. Influences of organizational culture and climate on individual creativity. The Journal of Creative Behavior. Vol 31, Iss.pg.27.

[12] Richard, A. Creating a climate and culture for sustainable organizational change. Journal Organizational Dynamics. New York: Spring 1996. Vol 24 Iss. 4 pg. 6.

[13] Wirawan. 2007. Cultur and Organizional Climate: Aplication Theory and Research . Jakarta: Salemba Empat.

[14] Stinger, Robert. 2002. Leadership and Organization Climate: The Cloud Chamber Effect. Upper Saddle River, NJ: Prentice Hall.

[15] Minner, John B. 1997. Industrial and Organizational Psychology. Mc. Graw Hill International Edition.

[16] Wiles, K. Lovell, J. T. 1983. Supervision for Better School (Fifth Edition). New Jersey: Prentice-Hall, Inc.

[17] Glickman, C. D. 1981. Developmental Supervision: Alternative Practices for Helping Teachers Improve Instruction. Alexandria, Va: Association for Supervision and Curriculum Development.

[18] Masaong, A. K. 2012. Supervision of Learning and Teacher Kapacity Development. Bandung: Alfabeta.

[19] Reid, H. L. Supervision to Enhance Educational and Vocational Guidance Practice: A Review. International Journal Education Vocational Guidance, Vol 10. pp. 191-205. 2010.

[20] Zangaro, G. A. Organizational Commitment: A Concept Analysis Nursing Forum, Vol. 36 No. 2. pp. 14-22. 2001.

[21] Mgqulwa, N, "The Relationship Between Organisational Commitment and Work Performance in an Agricultural Company, Tesis, Preller St, Pretoria: University of South Africa. 2008.

[22] Fadli, U. M., Fadili, D. A., dan Kartawijaya, Y. Effect Personal Competency with Work Comitmen in PT. PLN (PERSERO) Rayon Rengasdengklok. Jurnal Management, Vol. 09 No. 2. Pp. 577-589. 2012. 
[23] Chen, J.C., Silverthorne, C., and Hung, J.Y. Organization Communication, Job Stress, Organizational Commitment, and Job Performance of Accounting Professionals in Taiwan and America. Leadership \& Organization Development Journal, Vol. 27 No. 4. pp. 242-249. 2006.

[24] Forward, G. L. The Effects of Communication, Religiosity, and Organizational Support on Student Commitment at a Church-Related University”. Human Communication, Vol. 12 No. 1. pp. 33 - 52. 2009.

[25] Güney, S. Effects of Organizational Communication on Work Commitment: A Case Study on a Public Agency in Ankara. Business Management Dynamics Journal, Vol. 2 No.4. pp. 18-29. 2012.

[26] Ruswenda, U, Determinant factor of School Supervisor Academic Supervision in Kabupaten Kuningan", Tesis, Jakarta: Universitas Indonesia, 2011.

[27] Hamadi, 2011. Implementation Akademic Supervision in Premary School Kecamatan Kelapa Kampit Kabupaten Belitung Timur”. Tesis. Jakarta: Universitas Indonesia.

[28] Rodwell, John J. Rene Kienzle and Mark A. Shadur, The Relationship Among Work Related Perceptions Integral Role of Comunication, Human Resources Management Journal. Vol. 37.3, 1998. 